and "Sporadotrema is nothing else than a typical Carpenteria".

Without fully accepting all Hofker's conclusions, it may be said that his work has brought additional and important evidence of the extraordinar $r$ variability of these sedentary Foraminifera as compared with that of their allies which remain free throughout life.

This does not necessarily lead to the conclusion that specific discontinuity does not occur in any of the sedentary Foraminifera. That would be an extreme view which is not warranted by the facts. Such species as Sorosphaera depressa and Schizammina labyrinthica described by Heron-Allen and Earland in these papers seem to be good species. But it does suggest that in some cases such discontinuity has been lost or, perhaps, has not yet been gained, and that their survival depends not on the evolution of specific characters but on their extreme adaptability to the environment by their great variability.

Space does not permit comment on many other interesting features of these papers, but attention may be directed to the account given of the remarkable family the Pegididre which have an extraordinarily thick shell and an unusual system of apertures. In this paper there is a reproduction of Dr. Orbigny's original sketch for a drawing of Rotalia dubia, a longlost species now included in the Pegididæ.

$$
\text { S. J. H. }
$$

1 E. Heron-Allen and A. Earland. On the Pegididm, J. Roy. Mier. Soc., 1928. Vol. 48. Some New Foraminifera from the South Atlantic, Parts I., II., and III. Ibid., $1929 ; 1930$. Vols. 49 and 50 $\approx$ J. Hofker, Foraminifera of the Siboga Expedition, Part II.; 1930.

\title{
Angiosperm Origins.
}

G.

R. WIELAND has a very interesting discussion of the origin of Angiosperms in the Proceedings of the International Congress of Plant Sciences held at Ithaca, vol. 1, pp. 429-456 (George Banta Publishing Company, Menasha, Wisconsin, 1929). Naturally this account contains a particularly interesting recapitulation of the main features of the discoveries in the Cycadeoider with which the author's name is now linked through the genus Wielandiella, established as the result of Nathorst's fine reconstruction of difficult Swedish and Yorkshire material ; but this general account is particularly valuable as it synthesises the available material, in a problem which ranges the whole globe and a considerable part of geological time.

Wieland argues that the Jurassic was a time of leaf and carpellary change in the earlier Angiosperms, just as the Cretaceous was the time of continued stem and floral change in fully characterised Angiosperms. $\mathrm{He}$ points out that the abundance of Angiosperms in Cretaceous rocks is due not merely to the incroasing complexity in the phylum, but also to the greater thickness of the more and more recent plant beds. From this point of view he advises the botanist not to take too seriously the geologists' suggestion that the Angiosperms originated locally and suddenly ; rather this impression may be due to imperfections in the earlier plant record; thus he calculates that of Jurassic times our plant records represent perhaps a tenth of one per cent of the species then existent, and those recorded mainly by dissociated leaves, stems, etc., more rarely by flowers and fruits. Some impressions of interesting new, possibly Dicotyledonous, fruits are recorded from Rhætic plant beds of the Argentine. Wieland states that the fossil series of insects described from these beds " mark the Argentine Rhætic as one of the most important fossil localities in the world ".

Wieland concludes that there is every reason to regard the Angiosperms, "so far as actual descent goes, as old, quite as old as pines, and polyphyletic ". He points out also that, from studies of fossil forms, it is easy to get a false impression that giant forms predominated in fossil periods, where specialised types make up the bulk of the fossil series. But this conclusion is not justified; the Cordaites varied from types with leaves ten feet long to those with narrow grass-like blades. Wieland suggests that "the contrast between the flowers of Drimys, in some species about the size of those of the chickweed, and related flowers a foot across, has surely been paralleled many times in the geologic past ", so that many small fleshy forms of megasporophylls were probably grouped into seed cones allied to Wielandiella in Rhætic times.

\section{Fluctuations in Fisheries.}

$\mathrm{O}^{\mathrm{N}}$ April 12, 1929, the Conseil Permanent International pour l'Exploration de la Mer held in London a special meeting to discuss the present state of our knowledge concerning fluctuations in the abundance of the various year-classes of food fishes. So much interest is now being taken in this important branch of fishery research that no less than nineteen papers were read at the meeting, a full report of which has recently been published.*

When the Council entered upon its international collaboration thirty years ago, an enormous amount of work had to be done in the systematic determination of the various species, in ascertaining their geographical occurrence and distribution, and in locating their spawning grounds. As this work advanced, and more refined methods of biological analysis were brought to bear upon the steadily accumulating masses of data, it gradually became clear that to think only in terms of species was in-

* Fluctuations in the Abundance of the Various Year-Classes of Food Fishes. Consell Permanent International pour l'Exploration de la Mer. Rapports et Procès Verbaux des Réunions, vol. 65, pp. 188. (CopenRapports et Procès Verbaux des Réunions, vol. 65,
hague: Andr. Fred. Høst et Fils, 1930.) $7.25 \mathrm{kr}$.

No. 3177, Vor. 126] adequate, and new concepts of definite tribes or races of the various species had to be evolved in order more clearly to grasp the true state of affairs in Nature. Still further research revealed, moreover, that these newly discovered tribes themselves often occur in several more or less distinct groups, depending upon such factors as age, size, and sexual maturity.

These comparatively recent racial investigations, and especially the study of the varying age-distributions in the stock of our chief species of food fishes, have opened up new vistas of marine investigation. They have explained in many cases the amazing fluctuations in the yield obtained by the fishing industry from year to year, and, more important still, it has even been possible to forecast future fluctuations-an achievement of very considerable practical value.

A paper read by Dr. Harold Thomson outlining his work on the haddock may be taken as typical of this branch of marine research, and indicates the possibilities inherent in the results so far obtained. After discussing the incidence and amplitude of brood survival, Dr. Thomson proceeds to consider the 
possible causes underlying them. The following are suggested :

(a) Variation in the locality of the spawning ground. In the case of the haddock, the main centre of spawning activity may vary in position by so much as almost $2^{\circ}$ of latitude. The effect of this movement of location is probably mainly an indirect one in that it influences the primary distribution of the eggs and fry.

(b) The numbers and average age of the spawning fish. The spawning shoals are always composed ehiefly of haddock from three to six years old, and therefore include a series of broods differing in themselves in initial numerical strength. As there is an appreciable difference between the spawning locations assumed by younger and older haddock, the outcome may well be that the eggs and fry resulting from the spawning of younger fish predominating in one year will drift in quite a different set of currents from those resulting from the spawning of older fish predominating in another year.

(c) Early food supply. There is reason to suppose that the food requirements of the earlier (fry) stages are highly specialised, and that the necessary food organisms fall short of the demand to a greater or less extent in certain years. This, possibly, is the main cause underlying the not unusual wholesale failure of a brood.

Finally, as a result of careful analysis of the existing composition of the North Sea haddock, Dr. Thomson has been able to formulate the following tentative estimate of the immediate (1929) outlook for the fishery. "As the 1927 brood has proved to be almost a failure, catches may be expected to dwindle below the normal from the late autumn until well into next year (1930). About August of 1930 there should be a marked increase in the catches owing to the upgrowth of the very successful 1928 brood. In 1931 still greater catches should accrue. This is as far as can be seen ahead, for by the autumn of that year the influence of the 1928 brood will be waning and the next determining factor will be the quality, as yet unknown, of the brood of 1929. Estimations are therefore necessarily restricted to about two years ahead in the case of the southern portion of the North Sea. If these general anticipations prove correct an attempt should certainly be made to form seasonal or even monthly forecasts for the main fishing grounds."

Dr. Johan Hjort, in a brief survey of the methods and general principles underlying investigations into fluctuations in the stock of fishes, lays great stress upon the importance of the work. He suggests the setting up of an international biological organisation for the regular observation of age-distribution in the stock of our food fishes and of the relative-in time perhaps even the absolute - numerical strengths of the year-classes. Such a biological service, dealing conjointly with both biological statistics and a biochemical study of the fluctuating conditions in the sea, would in due course throw new light on many problems, and render possible a trustworthy fishery prediction service.

\section{Linnæus and the Production of Artificial Pearls.}

I INN EUS was a great naturalist, but one gathers 11 a fresh idea of his manifold interests in Nature from the series of articles in Svenska Linné-Sällskapets Arsskrift, Ârg. 13, 1930. One of the most curious of these papers, by Gustaf Drake, recounts an incursion of Linnæus into the artificial pearl trade. In the course of his journey through Lapland, Linnæus paid a visit to a pearl-fishery, where the pearls were derived from fresh-water mussels. Knowing that various species of mollusea, both fresh-water and marine, could produce pearls, he formed the opinion that theoretically they could be formed by any shell, and turned his attention to their artificial production. He carried out several successful experiments, and Beckmann records that in 1765 he was shown by Linnæus himself four or five real pearls lying within the shells of $M y a$ margaritifera, with the proud announcement: "hos uniones ipse artificio meo arcano confeci." Before this time, however, word had got abroad of Linnæus's pearlmaking secret, and in 1761-62 he was induced to demonstrate his method to Parliament. As a reward he was allowed the right of nominating his own successor, and chose his only son. But he also had a tempting offer from a private person for the monopoly of his pearl-producing method, though he did not accept it.

It is interesting to recall that the manuscripts explaining the pearl-producing method of Linnæus came into the hands of Sir James Smith and to repeat the latter's strong opinion regarding the exploitation of such scientific researches, conveyed in a letter dated Nov. 28, 1821: "The only pearls I ever expected from the possession of your illustrious countryman's literary treasures are pearls of science, in which I have not been disappointed. I am contented with these, and am happy that Sweden appears satisfied with what I have done for the honour of Linnæus and for the science to which I have devoted myself, in humble imitation of that great man. I believe
I am possessed of manuscripts of his own explaining the secret of producing pearls. I have also in his own cabinet of shells specimens of pearls so produced, and of mussel shells in various states upon which experiments have been made. I have no intention of carrying out the scheme-still less of paying $£ 500$ for any further information, nor, in short, of entering at all on the subject, for which I have no leisure." Can any of our readers say whether the experimental shells referred to are still in existence, and if so, whether the public has ever had an opportunity of seeing so interesting an exhibit ?

The natural philosophy of Linnæus is the subject of another very interesting contribution in the same Arsskrift. The Rev. Dr. Elis Malmeström considers that although Linnæus scarcely formulated a natural philosophy of his own, his ideas moved in the direction of such a philosophy, and in the preface and introductions to his various works he often indicated the direction of his thoughts about the universe, creation, life and its purpose. Three transitional stages of development are observable. In the first, ending about 1735, Linnæus expressed in the first edition of "Systema Naturae" a static idea of Nature which he had gathered from the Bible and especially from the creation myths of the Old Testament. Such an idea is presupposed by the whole of his systematic work, and he never really forsook it. The second period, up to about 1750 , saw an endeavour to unify the discrepancies which appeared to be increasing between creed and science. The fixity of species seemed less assured than formerly, but Linnæus stood firm against materialism, and adopted the physico-theology of his day. The third period, from 1750 until his death, marked a strong drift toward theodicy and a teleological view of Nature. He now adopted a natural theology, in which everything worked for the glory of God. Behind his thoughts on natural philosophy lay a religious craving for harmony. 